\title{
Rough Fescue Response to Season and Inten- sity of Defoliation
}

\author{
ALASTAIR MCLEAN AND SANDRA WIKEEM
}

\begin{abstract}
Rough fescue (Festuca scabrella Torr.) was subjected to 10 clipping regimes which varied in time or intensity of defoliation. The experiment was repeated at 2 sites for 3 consecutive years. Plant survival and vigor were evaluated the summer following defoliation. Clipping treatments involving weekly defoliation to a 5-cm stubble height from mid May to late June resulted in the greatest injury. Reduced injury occurred when clipping ceased in May or when 10 or $15 \mathrm{~cm}$ of herbage was retained. Season long defoliation to $20 \mathrm{~cm}$ or clipping only in the fall caused no apparent damage. Cutting in the fall plus spring resulted in greater injury than spring clipping alone on plants clipped from mid May to late June but a fall clipping effect was not observed consistently on plants clipped in May plus fall.
\end{abstract}

Despite common observances of rapid decline of rough fescue (Festuca scabrella Torr.)' on overgrazed ranges, little work has examined defoliation response of this productive grass. Root and top growth yields were reduced by repeated monthly clipping to stubble heights of $4\left(1 \frac{1}{2}\right), 7.5(3)$, or $12.5(5) \mathrm{cm}$ (inches) in a greenhouse study (Johnston 1961). Magnitude of root yield reduction from the $12.5-\mathrm{cm}$ treatment (comparable to $20 \%$ utilization) was much greater than reduction in herbage yield. Tiller production was depressed with the 2 most severe treatments but apparently was unaffected by the $12.5-\mathrm{cm}$ stubble height treatment. The author advised caution in interpretation of clipping trials since 20\% utilization on an Alberta fescue grassland indicated no depression of root or herbage yields. A long-term study (Johnston et al. 1971) showed that even light season-long grazing (0.8 ha/AUM) reduced rough fescue basal area after 16 years and the species was largely eliminated under very heavy grazing $(0.2$ ha/AUM). Long-term consequences of a grazing trial could not be determined after 6 years on a central Albertan rough fescuewestern porcupine grass (Stipa spartea Trin.) rangeland (Bailey et al. 1980) but heavy (75\%) utilization in either June or fall depressed grass production. Light (35\%) utilization results were similar to the controls. Fescue yields the year following mowing in another Alberta study (Sinton and Bailey 1980) were greater than the control for the April 8 treatment; but cutting late in spring (April 27 , June 1 ) or in fall (July 31 , Oct. 18) resulted in production losses. Tiller density increased and leaf length decreased for all mowing treatments but the effects were most pronounced for the fall cuttings. Of the spring mowing treatments, leaf lengths were shortest and tiller stimulation was slightest for the June 1 mowing.

In a previous paper, Stout et al. (1981) examined vegetative and reproductive growth of rough fescue. In the present study, response of rough fescue to a number of clipping regimes incorporating different times, frequencies and intensities of defoliation is compared.

\section{Study Areas}

Both the Hamilton and East Mara trials were conducted in

Authors are range ecologist and ecology technician, Agriculture Canada, Range Research Station, Kamloops, B.C.

The authors wish to thank Larry Haupt for technical help and John Hall, Agriculture Canada, Research Station, Vancouver, B.C., for statistical assistance.

Manuscript accepted June 21, 1984.

INomenclature according to Hitchcock and Cronquist (1973). long-standing exclosures which are located in the bluebunch wheatgrass-rough fescue (Agropyron-Festuca) zone. The Hamilton exclosure, fenced in 1931 and located $65 \mathrm{~km}$ southeast of Kamloops, B.C., supports a stand dominated by rough fescue $(\$ 2 \%$ cover in 1968) with moderate amounts of Junegrass (Koeleria cristata Pers.) and bluebunch wheatgrass (Agropyron spicatum (Pursh) Scribn. \& Smith) present. The site faces southeast on a 5\% slope at an elevation of $1,160 \mathrm{~m}$. The East Mara exclosure, fenced in 1938 and located $5 \mathrm{~km}$ west of Kamloops, has a greater proportion of rough fescue than the Hamilton site ( $76 \%$ cover in 1968 ) but also supports small amounts of Junegrass and bluebunch wheatgrass. The site faces northeast on a $25 \%$ slope at $855 \mathrm{~m}$ elevation. Both sites have a Black Chernozemic soil (Haploboroll) of sandyloam texture. Environmental data collected during the study are given in Stout et al. (1981).

\section{Experimental Procedure}

This experiment was closely patterned after a bluebunch wheatgrass clipping trial conducted at different sites (McLean and Wikeem 1985). Six clipping treatments were selected to simulate timing and duration of possible grazing regimes and another 4 varied only in clipping intensity (stubble height). The experiment was repeated from 1971 to 1973 with different plants being used for each year of the study. Prior to spring clipping, 10 rough fescue plants were randomly selected from a virtually pure stand for each clipping treatment and for an unclipped control. Basal area was measured, then the plants were labelled and clipped weekly according to the schedule given in Figure 1. Clipping commenced when growth reached $10 \mathrm{~cm}$. Clipping height was $5 \mathrm{~cm}$ unless otherwise indicated. Vegetation surrounding the selected plants was not cut.

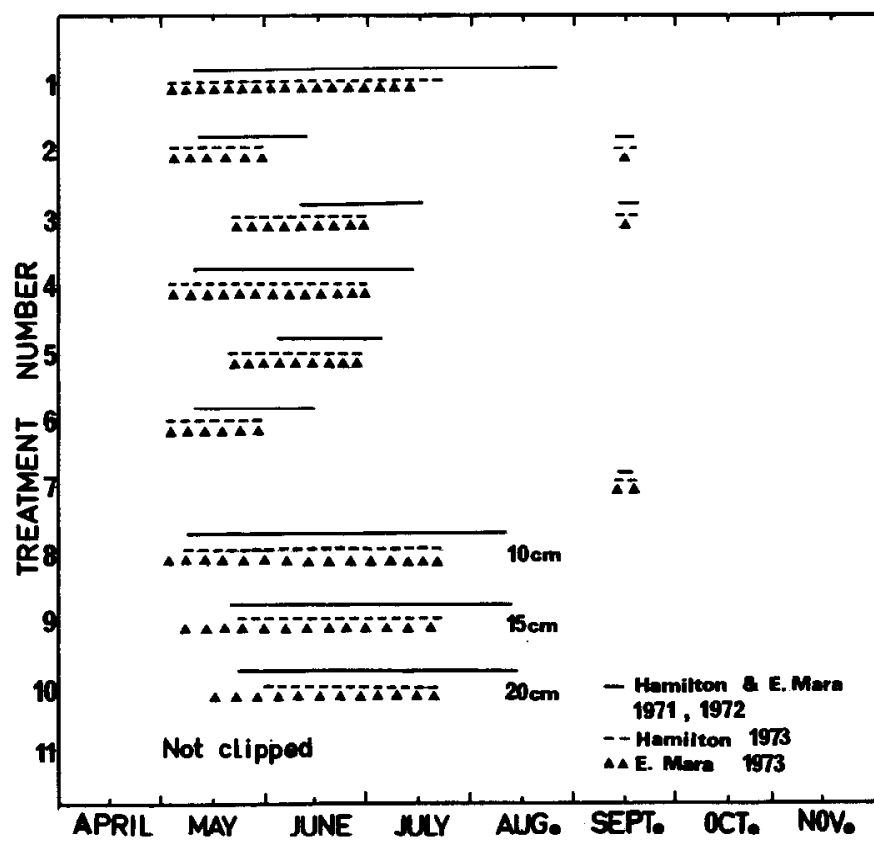

Fig. 1. Schedule of the 10 clipping treatments. Clipping heights were $5 \mathrm{~cm}$ unless otherwise noted. 
Table 1. Average percent kill of rough fescue plants in summer the year following clipping at two southern British Columbia locations.

\begin{tabular}{|c|c|c|c|c|c|c|c|}
\hline \multirow{2}{*}{$\begin{array}{c}\text { Treatment } \\
\text { number }\end{array}$} & \multirow{2}{*}{$\begin{array}{l}\text { Pooled means } \\
\quad(3 \mathrm{yr})\end{array}$} & \multicolumn{3}{|c|}{ East Mara } & \multicolumn{3}{|c|}{ Hamilton } \\
\hline & & $1971^{1}$ & 1972 & 1973 & 1971 & 1972 & 1973 \\
\hline 1 & $76 \mathrm{f}^{2}$ & $81 \mathrm{~g}$ & $79 \mathrm{~g}$ & $83 \mathrm{e}$ & $66 f$ & $77 \mathrm{f}$ & $76 \mathrm{e}$ \\
\hline 2 & $27 \mathrm{de}$ & $34 \mathrm{~d}$ & $31 \mathrm{c}$ & $20 \mathrm{~cd}$ & $42 \mathrm{e}$ & $15 \mathrm{c}$ & 22 bc \\
\hline 3 & $92 \mathrm{~g}$ & $97 \mathrm{~h}$ & $97 \mathrm{~h}$ & $95 \mathrm{f}$ & $89 \mathrm{~h}$ & $90 \mathrm{~g}$ & $86 \mathrm{e}$ \\
\hline 4 & $79 \mathrm{f}$ & $82 \mathrm{~g}$ & $69 \mathrm{fg}$ & $90 \mathrm{ef}$ & $78 \mathrm{~g}$ & $66 \mathrm{e}$ & $89 \mathrm{e}$ \\
\hline 5 & $71 \mathrm{f}$ & $65 \mathrm{f}$ & 65 ef & $88 \mathrm{e}$ & $78 \mathrm{~g}$ & $63 \mathrm{e}$ & $84 e$ \\
\hline 6 & $25 \mathrm{~cd}$ & $25 \mathrm{c}$ & $27 \mathrm{c}$ & $26 d$ & $35 \mathrm{de}$ & $17 c$ & $21 \mathrm{bc}$ \\
\hline 7 & $6 a$ & $5 a$ & $0 \mathrm{a}$ & $11 \mathrm{bc}$ & $7 \mathrm{a}$ & $2 a$ & $15 \mathrm{ab}$ \\
\hline 8 & $35 \mathrm{e}$ & $44 \mathrm{e}$ & $49 \mathrm{~d}$ & $18 \mathrm{~cd}$ & $28 \mathrm{~cd}$ & $42 \mathrm{c}$ & $29 \mathrm{bc}$ \\
\hline 9 & $17 b c$ & $23 \mathrm{c}$ & $17 \mathrm{~b}$ & $15 \mathrm{c}$ & $19 \mathrm{bc}$ & $11 \mathrm{bc}$ & 17 bc \\
\hline 10 & $9 \mathrm{ab}$ & $13 \mathrm{~b}$ & $9 \mathrm{ab}$ & $6 a b$ & $9 \mathrm{ab}$ & $5 a b$ & $9 \mathrm{ab}$ \\
\hline 11 & $1 \mathrm{a}$ & $11 \mathrm{a}$ & $0 \mathrm{a}$ & $0 \mathrm{a}$ & $2 a$ & $0 \mathrm{a}$ & $2 a$ \\
\hline Avg. & 40 & 44 & 40 & 41 & 41 & 35 & 41 \\
\hline S.E. & 3.3 & 1.9 & 3.5 & 2.5 & 3.6 & 2.9 & 4.6 \\
\hline
\end{tabular}

'Year plants were clipped.

¿Means within a column followed by the same letter are not significantly different $(P \leqq 0.05)$ according to Duncan's multiple range test.

Phenological stage and leaf height of control plants were noted weekly throughout the clipping schedule.

Unlike the bluebunch wheatgrass trial, fescue phenology did not differ greatly between locations. As treatments 1, 8, 9 and 10 simulated season-long grazing, onset and duration of clipping was variable. Cutting for most spring clipping treatments began approximately 10 days earlier in 1973 than in 1971 and 1972 because of early spring growth but initial cuttings of treatments 9 and 10 were delayed while waiting for plants to exceed the prescribed stubble height.

The summer following defoliation, mortality (percent kill) was visually assessed on each fescue plant, including the controls. Leaf heights, tiller numbers, flowering culm numbers and yields were collected as measures of plant vigor. Dry matter yields were obtained by clipping plants to $5 \mathrm{~cm}$, bulking the herbage for each treatment, and then oven drying and weighing the samples.

Air temperature and precipitation were monitored continuously and soil temperatures and moisture contents (gravimetric) were collected biweekly from April to September at each site. Stout et al. (1981) present and discuss environmental data collected over the course of the study.

Clipping treatment, location, and year effects were analyzed statistically using analysis of variance. Basal area was detectably related $(P \leq 0.05)$ to leaf height and tiller number so was used as a covariate in analysis of covariance for these 2 variables. Seed head numbers were not analyzed because the number of flowering culms was too low and inconsistent to provide a meaningful analysis.

Each variable was analyzed with sites and years combined (three-factor analysis) and percent kill, the variable of primary interest, was analyzed for each site in each year (one-factor analysis). Year, a random effect, was considered a replication in the combined analysis. The year by treatment (location and clipping) interaction term was used to test main effects, as variability attributed to the interaction far exceeded experimental error variation. The third-order interaction term (year $\times$ location $\times$ clipping) was used as a measure of error for yield as there was only one observation per experimental unit. Clipping treatment means were separated with Duncan's multiple range test $(P \leq 0.05)$. Orthogonal polynomials were used in the combined analyses to determine the relationship between clipping height and the variable measured.

\section{Results}

\section{Percent Kill}

Plant mortality varied significantly among clipping regimes for each site in all years and when sites and years were pooled (Table 1). Greatest mortality occurred when plants were clipped weekly to $5 \mathrm{~cm}$ from mid May to late June and then once in early September to remove regrowth (treatment 3). Although treatment 1 plants, which were clipped season long to $5 \mathrm{~cm}$, suffered high mortality, their pooled mean mortality as well as that for most of the individual site-years, was significantly lower than mortality of treatment 3 plants. Percent kill was high also on treatments 4 (clipped May and June) and 5 (clipped mid May to late June but not in September) plants. Treatments 2 (May plus September regrowth), 6 (May only), and 8 and 9 (season-long defoliation to 10 and $15 \mathrm{~cm}$ respectively) resulted in moderate to heavy injury. No significant difference existed between the unclipped control and fall only defoliation (treatment 7 ) or season-long clipping to $20 \mathrm{~cm}$ (treatment 10). Percent kill decreased curvilinearly as stubble height increased; with each $5-\mathrm{cm}$ increase in clipping height mortality decreased by roughly half.

In the combined analysis, percent kill means for spring plus fall clipping treatments compared to spring only defoliation differed significantly for treatments 3 and 5 (mid May to late June defoliation) but not for treatments 2 and 6 (May clipping). Individual site-year means generally exhibit this same result.

Average mortality over the 3 years of the study did not differ significantly between sites nor was there a location by treatment interaction. There was a significant year effect; percent kill averaged 38\% following 1972 clipping and $41 \%$ following 1971 and 1973. Year interacted significantly with location plus clipping treatment. Possibly the interaction can be attributed to treatments 2 and 6 as mortality from these treatments was greater after 1972 than 1973 at the East Mara site but the reverse was true at the Hamilton site.

\section{Leaf Height, Tiller Number, and Yield}

Leaf heights, number of tillers, and forage yield, all indicators of plant vigor, were inversely related to percent kill, i.e., plants subjected to treatments resulting in the lowest mortality had the tallest leaves, most tillers, and greatest yields. In general, means of these variables were arrayed similarly to percent kill by Duncan's multiple range test (Table 2) although there were minor differences. For example, mean yield of treatment 10 plants differed significantly from the unclipped control while the other variables did not. Also, treatment 3 was not separated from treatments 4 and 1 for any of the vigor indicator parameters as it was with percent kill.

Leaf height, tiller number, and yield were all related linearly to clipping height and none had a significant location by clipping treatment interaction. Average leaf heights were significantly taller at East Mara $(28 \mathrm{~cm})$ than at Hamilton $(25 \mathrm{~cm})$ and were taller following $1971(28 \mathrm{~cm})$ than 1972 or 1973 clippings $(25 \mathrm{~cm}$ both years). A year by location and clipping treatment interaction may have resulted from treatments 3 and 5 plant response following the Hamilton 1973 clipping. This was the only case where treatment 3 
Table 2. Leaf height, tiller number and yields the year following clipping averaged over the 3 years and two sites in southern British Columbia.

\begin{tabular}{cccc}
\hline \hline $\begin{array}{l}\text { Treatment } \\
\text { number }\end{array}$ & $\begin{array}{c}\text { Leaf height } \\
(\mathrm{cm})\end{array}$ & $\begin{array}{c}\text { Tiller number } \\
\text { per plant }\end{array}$ & $\begin{array}{c}\text { Yield }(\mathrm{g}) \\
\text { per plant }\end{array}$ \\
\hline 1 & $20.8 \mathrm{ab}^{2}$ & $65.1 \mathrm{ab}$ & $2.2 \mathrm{a}$ \\
2 & $26.2 \mathrm{~cd}$ & $147.0 \mathrm{~cd}$ & $6.3 \mathrm{bcd}$ \\
3 & $17.6 \mathrm{a}$ & $41.3 \mathrm{a}$ & $1.1 \mathrm{a}$ \\
4 & $21.6 \mathrm{ab}$ & $56.8 \mathrm{ab}$ & $1.6 \mathrm{a}$ \\
5 & $22.6 \mathrm{bc}$ & $78.2 \mathrm{ab}$ & $2.7 \mathrm{ab}$ \\
6 & $28.7 \mathrm{de}$ & $156.1 \mathrm{~cd}$ & $6.7 \mathrm{~cd}$ \\
7 & $31.8 \mathrm{e}$ & $243.5 \mathrm{ef}$ & $12.1 \mathrm{ef}$ \\
8 & $26.6 \mathrm{~cd}$ & $110.4 \mathrm{bc}$ & $4.8 \mathrm{abc}$ \\
9 & $28.1 \mathrm{de}$ & $197.9 \mathrm{de}$ & $8.6 \mathrm{de}$ \\
10 & $30.6 \mathrm{de}$ & $239.0 \mathrm{ef}$ & $11.0 \mathrm{e}$ \\
11 & $32.4 \mathrm{e}$ & $284.5 \mathrm{f}$ & $15.2 \mathrm{f}$ \\
S.E. & 1.4 & 18.0 & 1.2 \\
\hline
\end{tabular}

'Leaf height and tiller number means adjusted for basal area.

2 Means within a column followed by the same letter are not significantly different ( $P \subseteq 0.05$ ) according to Duncan's multiple range test.

leaf lengths exceed those of treatment 5. Plants from the Hamilton site averaged more tillers (adjusted to account for basal area) than those from East Mara (159 vs 135). Tiller number varied among years with an average of 178,133 , and 131 for 1971 through 1973 clipping years, respectively. The year by treatment and location interaction may have resulted from several sources. As mentioned above, Hamilton plants averaged the most tillers, but treatments 2 , 5,6, and 10 plants had more tillers at East Mara following the 1971 clipping. With treatment 10 plants, the fewest tillers were counted at East Mara from the 1972 clipping, while at Hamilton, tillers were fewest following 1973.

Yields did not differ between location but did differ among years. Yields were notably higher the year following $1971(9 \mathrm{~g} /$ plant $)$ clipping treatments than yields following $1972(5 \mathrm{~g})$ or $1973(6 \mathrm{~g})$ defoliations.

\section{Discussion}

The most vulnerable periods for rough fescue defoliation were clearly demonstrated. Any treatments involving clipping to $5 \mathrm{~cm}$ from mid May to late June $(1,3,4,5)$ resulted in high mortality and severely reduced vigor in surviving plants. Clipping for these treatments began near the end of the rapid growth phase and continued past the end of leaf growth (phenological development is discussed in Stout et al. 1981). When clipping ceased before the end of vegetative growth (treatments 2 and 6) or when more photosynthetic surface was retained (treatments $8,9,10$ ) injury was reduced. Sinton and Bailey (1980) also observed reduction in vigor from late-spring cuttings.

The need for opportunity for regrowth has been stressed for bluebunch wheatgrass (Stoddart 1946) and appears to be important for rough rescue also. In this study, plants which received their last defoliation while growth was still active produced considerably more regrowth than plants which did not; treatment 2 plants averaged $3.2 \mathrm{~g}$ of regrowth, while treatment 3 plants averaged only $1.3 \mathrm{~g}$. Low injury for treatments 2 and 6 plants following the 1972 clipping at the Hamilton site (Table 1) further illustrates the importance of length of time for regrowth. Leaf growth at Hamilton in 1972 extended approximately 3 and 4 weeks longer than in 1971 and 1973, respectively, but little injury reduction was observed at East Mara in 1972 where leaf growth extended only about 1 week longer than in the other years.

Fall clipping alone (treament 7) affected neither survival nor vigor adversely. Removal of regrowth in the fall in addition to spring defoliation, however, resulted in greater injury to the mid May - late June clipping treatment (3). In most cases cutting in May plus September (2) caused no significantly greater injury than clipping only in May. It is not readily apparent why treatment 3 plants responded so negatively to the additional fall cutting. While rough fescue carbohydrate utilization and accumulation trends are unknown, we might surmise that regrowth drew further on already depleted stores and that removal of herbage in early September would have precluded carbohydrate production in autumn. Since regrowth on treatment 3 plants was very slight, with an average of $1.1 \mathrm{~g}$ dry weight per plant at Hamilton and $0.4 \mathrm{~g}$ at East Mara, it seems unlikely that so little biomass should cause much more depletion. The answer may be in high photosynthetic rates of regrowing tissues such as was reported by Caldwell et al. (1981) for crested wheatgrass and bluebunch wheatgrass. Perhaps in this study, fescue regrowth, although slight, was photosynthetically active enough to replenish carbohydrate reserves significantly during the fall providing herbage was not removed. Plants clipped in May (treatment 2) which did not exhibit increased injury from fall defoliation may have accrued enough carbohydrates during the period between defoliation and summer dormancy to be less dependent on reserves accumulated through fall photosynthesis. A relationship between time of defoliation, subsequent regrowth and autumn carbohydrate levels was observed in a crested wheatgrass study (Trlica and Cook 1972). Although initial regrowth following an early spring (April) defoliation drew heavily on carbohydrate stores, enough photosynthetic tissue was produced to bring carbohydrate concentrations near those of the control by autumn. Plants clipped later in early June produced less regrowth and had greatly reduced carbohydrate concentrations in the fall.

Studies designed to assess effects of defoliation on fescue carbohydrate trends might be able to explain this fall clipping effect. Whatever the underlying explanation, the fall clipping response probably caused the difference between mortality of treatment 3 and treatments 1 and 4 plants. Since both treatments 1 and 4 involved clipping to $5 \mathrm{~cm}$ through the rapid growth phase and past the end of leaf growth, they would be expected to cause mortality at least equal to that of treatment 3 . The fall defoliation appears to be the only factor separating treatment 3 from the other two.

There were many similarities between the bluebunch wheatgrass and rough fescue trials (McLean and Wikeem 1985). In both trials, treatments which extended past the cessation of leaf growth caused greatest injury while treatments which either increased stubble height or ended earlier were less harmful. There were some differences. The fall plus spring clipping response was less clearly defined in the bluebunch wheatgrass study and treatment 1 was more severe than treatment 3. Possibly rough fescue under stress may be more dependent on regrowth for reserve repletion.

Percent kill of the 2 species cannot be compared statistically as the 2 trials were conducted at different locations. Data from the 2 most similar sites, Minnie Lake (bluebunch wheatgrass) and Hamilton (rough fescue), which are located only $2 \mathrm{~km}$ apart on similar soils, slopes, and aspects, suggest that bluebunch wheatgrass is more sensitive to season-long defoliation ( $99 \%$ average kill for treatment 1 compared to $76 \%$ for fescue) or clipping during early spring ( $42 \%$ versus $27 \%$ for treatment 2 ). Again an understanding of fescue carbohydrate trends and their relationships to defoliation may explain this apparent difference.

\section{Literature Cited}

Bailey, A.W., W.M. Trabysh, and W.D. Willms. 1980. Forage and beef production from rough fescue rangeland. Agr. and Forest Bull. Univ. Alberta (1980) Special.

Caldwell, M.M., J.H. Richards, D.A. Johnson, R.S. Nowak, and R.S. Dzurec. 1981. Coping with herbivory: photosynthetic capacity and resource allocation in two semiarid Agropyron bunchgrasses. Oecologia (Berl.) 50:14-24.

Hitchcock, C.L., and A. Cronquist. 1973. Flora of the Pacific Northwest. Univ. Washington Press, Seattle.

Johnston, Alexander. 1961. Comparison of lightly grazed and ungrazed range in the fescue grassland of southwestern Alberta. Can. J. Plant Sci. 41:615-622. 
Johnston, A., J.F. Dormaar, and S. Smoliak. 1971. Long-term grazing effects on fescue grassland soils. J. Range Manage. 24:185-188.

McLean, A., and S. Wikeem. 1985. Influence of season and intensity of defoliation on bluebunch wheatgrass survival and vigor in southern British Columbia. J. Range Manage. 38:21-26.

Sinton, H.M., and A.W. Bailey. 1980. Burning versus mowing: effects on rough fescue rangeland. Agr. and Forest. Bull., Univ. Alberta (1980) Special.

Stoddart, L.A. 1946. Some physical and chemical responses of Agropyron spicatum to herbage removal at various seasons. Utah Agr. Exp. Sta. Bull. 324.
Stout, D.G., A. McLean, and D.A. Quinton. 1981. Growth and phenological development of rough fescue in interior British Columbia. J. Range Manage. 34:455-459.

Tisdale, E.W. 1947. The grasslands of the southern interior of British Columbia. Ecology 28:346-381.

Trlica, M.J., and C.W. Cook. 1972. Carbohydrate reserves of crested wheatgrass and Russian wild rye as influenced by development and defoliation. J. Range Manage. 25:430-435. 